\title{
A gamificação e o ensino/aprendizagem de segunda língua: um olhar investigativo sobre o Duolingo
}

\author{
Cláudio Corrêa ${ }^{1}$ \\ Programa de Pós-Graduação em Letras, Universidade do Estado do Rio de Janeiro (UERJ), \\ Rio de Janeiro, RJ, Brasil
}

Resumo: Este estudo aborda como ocorre o ensino/aprendizagem de segunda língua - por meio da educação online aberta - procurando-se responder se é possível aprender uma língua adicional e "como" isso acontece, tendo como viés o uso de tecnologias digitais e a gamificação do ensino. $O$ objetivo foi alcançado por meio de um estudo qualitativo sobre o curso/aplicativo Duolingo - que se propõe a ensinar línguas utilizando características de gamificação. $O$ artigo se baseia em uma pesquisa qualitativa para a qual foram selecionados participantes adultos - falantes nativos de língua portuguesa, que não tiveram instrução formal da língua-alvo -, que fizeram testes de nivelamento comparativos (iniciais e finais), com o propósito de averiguar a aprendizagem. Também foram agregados outros meios digitais de educação aberta, disponíveis para prática, interação, aperfeiçoamento e desenvolvimento de competência linguística.

Palavras-chave: Ensino/aprendizagem de segunda língua; Ensino online aberto; Gamificação; Tecnologias digitais.

Title: Gamification and second language teaching/learning: an investigative look at Duolingo

Abstract: This study approaches how second language teaching/learning occurs - in open online education - seeking to answer if it is possible to learn an additional language and "how" this happens, taking as a bias the use of digital technologies and the gamification of teaching. The objective was achieved by means of a qualitative study on the course/application Duolingo - which proposes to teach languages using gamification characteristics. This is a qualitative research in which adult participants - native speakers of Portuguese language, who did not have formal instruction in the target language - were selected and did comparative (initial and final) placement tests, with the purpose of ascertaining learning. The basic course chosen for the participants was Duolingo. Other digital sources of open online education, available for practice, interaction, improvement and development of linguistic competence, were also added.

Keywords: Second language teaching /learning; Open online education; Gamification; Digital technologies.

\footnotetext{
${ }^{1}$ Doutorando em Linguística (PPG em Letras da Universidade do Estado do Rio de Janeiro - UERJ). Orcid: https://orcid.org/0000-0002-4383-9207

E-mail: correadtp@gmail.com
} 


\section{Introdução}

Este trabalho tem como objetivo apresentar os resultados de um estudo qualitativo sobre o curso/aplicativo Duolingo - que se propõe a ensinar línguas utilizando características de gamificação. As principais questões que nortearam a pesquisa foram estas: $E$ possível aprender uma segunda língua por meio do Duolingo? Como a gamificação no ensino de línguas é utilizada por esse curso? e Como as tecnologias digitais contribuem para isso?

Muitos já disseram que "é possível aprender" e outros tantos que "não é possível aprender" línguas por meio do Duolingo. Então, para resolver esse impasse, essa pesquisa foi realizada. O objetivo geral, portanto, é a aprendizagem de segunda língua por meio da educação online aberta ${ }^{2}$ e isso foi feito procurando-se responder se é possível aprender uma segunda língua - e com isso se dá -, tendo como viés o uso de tecnologias digitais e gamificação do ensino. O objetivo específico foi contemplado por meio de um estudo qualitativo sobre o curso/aplicativo Duolingo, além de outros recursos presentes na educação aberta online.

O tema escolhido mereceu ser alvo de uma investigação cuidadosa devido à grande evolução - ocorrida nos últimos anos - das tecnologias digitais; e, neste estudo, em particular, da consequente ampliação das oportunidades de ensino online aberto para a aprendizagem de segunda língua (que atinge milhões de pessoas no mundo).

Surgiu a curiosidade em saber até onde pode chegar aquele que se propõe a aprender e opta por esse caminho. Daí a motivação em investigar as reais vantagens/desvantagens que as tecnologias digitais propiciam, em especial as que permitem acesso à internet. Sem querer fazer uma limitação "rotuladora e reducionista", o aprendiz pode carregar com ele a sala de aula e o professor para todo lugar. Sem ficar preso ao ambiente escolar.

A relevância para a sociedade, diante deste quadro - de invasão das tecnologias digitais no ensino/aprendizagem de segunda língua -, justifica-se pelo número de pessoas que têm acesso a essas plataformas, cada vez mais difundidas, e que se não atingem a todos, já o fazem em números bem maiores que as escolas tradicionais. Portanto, faz-se necessário um mergulho profundo para desvelar essa real contribuição na aprendizagem de segunda língua.

Ao final deste estudo, apresentam-se perspectivas, fazem-se sugestões no âmbito da realidade investigada e propõem-se caminhos que contribuam para o aperfeiçoamento do ensino online aberto gratuito. A relevância desta pesquisa pode também ser justificada pelo fato de que a opção por esses cursos/aplicativos (nesta pesquisa, restringidos aos abertos) têm sido feita por milhões de usuários em todo o mundo. Estamos acostumados aos grandes centros urbanos, nos quais proliferam cursos de idiomas (em sua maioria pagos), e, muitas

\footnotetext{
${ }^{2}$ Neste trabalho, utilizou-se o conceito de educação online aberta como sinônimo de gratuita, sem assinaturas, pagamentos ou restrições de qualquer espécie. Portanto, não no sentido de permitir adaptações e alterações profundas em sua estrutura e recursos.
} 
vezes, nos esquecemos dos que habitam as periferias (sejam elas econômico-sociais ou geográficas).

\section{O que é gamificação (potencial no ensino/aprendizagem)}

O termo gamification (gamificação) surgiu por volta de 2002 e é atribuído a Nick Pelling, programador de computadores nascido na Inglaterra, na década de 1960. Originalmente cunhado para descrever a aparência de interfaces similares às dos games (jogos), acabou evoluindo com o passar do tempo e, atualmente, uma boa definição sobre seu significado foi feita por Kapp (2012): "gamificação é a utilização de mecânica, estética e pensamento baseados em games para engajar pessoas, motivar a ação, promover a aprendizagem e resolver problemas".

Em outras palavras, gamificação é o uso de estratégias de games - com seus aspectos, mecanismos e dinâmicas - que visam ao engajamento das pessoas para alcançar objetivos, superar metas, resolver problemas, vencer desafios, melhorar a aprendizagem, motivar, dar feedback imediato... Enfim, utilizar como base a maneira de fazer as coisas do jeito como são concebidas nos jogos, e, cujas características puderam ser potencializadas nos meios digitais. Não é tirar as pessoas do mundo real, mas incorporar as qualidades dos jogos para executar as tarefas (missões) de maneira gratificante.

Os jogos, em geral, já fazem isso há milênios, mas as tecnologias digitais facilitaram a aplicação da gamificação em várias áreas, cumprindo seu intuito de fazer com que as pessoas consigam executar tarefas - que elas já faziam de um modo ou de outro - só que de forma aprazível. Ao promover o engajamento de indivíduos digitalmente - por meio da interação com computadores, celulares, tablets e demais dispositivos - a gamificação tem o objetivo de motivar as pessoas para que desenvolvam habilidades e competências e atinjam suas metas.

Ao entrar em um jogo você recebe uma "missão", não qualquer "missão", mas uma perfeitamente adequada ao seu atual nível no jogo. Os game designers (criadores de jogos) têm a preocupação de que você consiga cumpri-la, porém, sempre no limite da sua capacidade, é preciso se esforçar - nada é dado de graça. Ultrapassar as fases compreende desafio, motivação, colaboração, feedback, recompensa... coisas que, na maioria das vezes, são esquecidas na vida real e, em se tratando de educação, parece até que são coisas incompatíveis, na medida em que são rotuladas como com ou sem qualidade ou fins pedagógicos. Misturar entretenimento e diversão com ensino sério, às vezes, para alguns, é quase uma ofensa (CARDOSO, 2014). 
Segundo pesquisas realizadas na Carnegie Mellon University ${ }^{3}$, nos países com uma cultura de jogos digitais bem desenvolvida, um jogador de 21 anos de idade terá gasto em média 10 mil horas jogando, um número bem próximo ao de horas gastas na educação regular no período entre o segundo segmento do ensino fundamental e a graduação (calculado em cerca de 12 mil horas em média). O que significa que há um tempo quase igual, correndo em paralelo ao da educação oficial, que está com seu potencial sendo subutilizado.

Por que não juntar o que há de bom nesses dois mundos (o educacional e o dos jogos)? Nos ambientes virtuais dos jogos digitais temos acesso a todo tipo de colaboração, seja do próprio jogo, de outros jogadores, de dicas dos especialistas que se proliferam em diversos canais na web; feedbacks imediatos, recompensas, pontos e poderes extras; novos desafios a todo momento; atitudes motivacionais e incentivadoras. Já nos ambientes educacionais instrucionais existe a velha e clássica definição de jogos de entretenimento ou diversão e os jogos educacionais ou com fins pedagógicos.

Os jogadores acreditam que podem mudar as coisas; que podem superar obstáculos; que têm grande chance de sucesso; vencer é possível. Compete, então, aos educadores transpor essa mentalidade para o mundo educacional. Entretanto, essa travessia tem que ser feita sem que se transforme o que os jogos têm de melhor - ou seja, as características acima citadas - em uma coisa "chata". Não dá para tratar jogos de entretenimento ou diversão e os jogos educacionais ou com fins pedagógicos como coisas distintas ou incompatíveis. Talvez demore um pouco, mas o potencial da gamificação é enorme e não pode ser desprezado.

\section{A geração digital}

Sobre essa temática, Prensky (2001) em seu artigo Digital Natives, Digital Immigrants, trata dos alunos do século XXI, principalmente na realidade norte-americana, mas sua abordagem corrobora com o recorte feito para esta pesquisa, ainda que numa abrangência bem menor em se tratando de países em desenvolvimento e se aplica ao nosso sistema educacional também. Ele começa o texto afirmando: "Nossos alunos mudaram radicalmente. Os alunos de hoje não são os mesmos para os quais o nosso sistema educacional foi criado." (PRENSKY, 2001, p. 1)

O autor levanta a hipótese de que os alunos de hoje pensam e processam as informações de modo bem diferente do que as gerações anteriores e acrescenta que, se as mentes dos alunos não mudaram fisicamente, com certeza, os modelos de pensamento mudaram. A esta nova geração, ele chama de nativos digitais, pois são "falantes nativos" da linguagem digital (dos computadores, celulares, games, internet...). E chama de imigrantes

\footnotetext{
${ }^{3}$ Citação feita pela game designer Jane McGonigal, na conferência Gaming can make a better world. Disponível em <https://www.ted.com/talks/jane_mcgonigal_gaming_can_make_a_better_world $>$. A Carnegie Mellon University, com sede na Pensilvânia, EUA, é uma das universidades mais bem ranqueadas do mundo na área tecnológica.
} 
digitais aos que não nasceram no mundo digital - mas que se esforçam por aprender e adotar as tecnologias digitais.

Os imigrantes digitais aprendem a adaptar-se ao ambiente (uns mais, outros menos), mas, geralmente, eles mantêm uma espécie de "sotaque", resquício das experiências vividas. Ou seja, utilizam linguagens ou modos de pensar anteriores à era pré-digital para alunos que possuem uma linguagem totalmente nova. Os nativos digitais, por sua vez, estão acostumados a receber informações muito rapidamente; gostam de processar mais de uma coisa por vez; realizar múltiplas tarefas; preferem acesso aleatório e não linear; adoram gratificações instantâneas e recompensas frequentes; preferem jogos a "trabalhos sérios".

Contudo, ainda há uma quantidade razoável de professores imigrantes digitais ainda considera que os novos alunos são iguais aos que eles foram, e que, portanto, os mesmos métodos que funcionaram antes, continuarão sendo eficazes. Estes professores, em relação à metodologia, precisam aprender a se comunicar na linguagem e estilo de seus estudantes nativos digitais, mas isso não significa mudar tudo, muito menos o que é realmente importante. E nem é preciso inventar do "zero", pois já há algumas alternativas de sucesso, entre elas, está a gamificação do ensino.

Prensky (2001) dá um exemplo que esclarece isso: um grupo de professores norteamericanos solicitou sua ajuda para ensinar como operar de um software de $C A D^{4}-$ que apesar de ser melhor que o mais usado no mercado por engenheiros, encontrava resistência, pois requeria muitas horas de aprendizagem; a partir da constatação de que os engenheiros, com cerca de 20 a 30 anos de idade, gostavam de videogames, resolveram, então, criar um jogo no qual a única maneira de derrotar o vilão era por meio da utilização do software de CAD. O jogo seguiu os padrões do mercado e resultou em um enorme sucesso para atrair os jovens a conhecerem o programa com mais de 1 milhão de cópias vendidas à época.

Durante o processo de criação do jogo, enquanto foi relativamente fácil para os nativos digitais inventarem o jogo, os imigrantes digitais sofreram um pouquinho, pois estavam acostumados a ensinar de modo tradicional, por exemplo: "Lição 1: interface"; "Lição 2..." Foi pedido aos professores (imigrantes digitais) que criassem tarefas que envolvessem as habilidades a serem aprendidas e para isso eles elaboraram vídeos de 5 a 10 minutos, e, na sequência, reduzidos para 30 segundos. Os professores insistiram que todo o conteúdo era necessário e que se seguisse uma ordem de execução das tarefas; os criadores queriam acesso aleatório. Enfim, para viabilizar o projeto contratou-se um roteirista de cinema de Hollywood.

Enquanto os professores queriam a linguagem pedagógica tradicional de objetivos de aprendizagem, os nativos digitais precisavam eliminar qualquer traço de educação formal. No fim das contas, alcançou-se êxito na empreitada, mas gastou-se o dobro do tempo esperado.

\footnotetext{
${ }^{4} \mathrm{CAD}$, do termo em inglês Computer-Aided Design (desenho auxiliado por computador), é o nome genérico de softwares utilizados como ferramentas que facilitam a criação de projetos e desenhos técnicos, muito comuns nas áreas de engenharia, arquitetura, elétrica, geologia, geografia..., bem como de seus produtos (edificações, vestuários, componentes eletroeletrônicos, automobilísticos, etc.). Os jargões de cada especialidade são incorporados na interface dos respectivos programas.
} 
Mas ao verem a técnica em prática, o modelo dos nativos digitais tornou-se o deles também e a velocidade de desenvolvimento aumentou vertiginosamente.

Embora várias tentativas de juntar educação e entretenimento tenham fracassado, é possível fazer muito melhor do que tem sido feito. Em vez de lamúrias, é preciso agir e fazer, com isso, cedo ou tarde, o sucesso virá. Não cabe mais ter a falsa presunção de que a sua maneira de ensinar é a única. Se a intenção é alcançar todos os estudantes (inclusive os nativos digitais), é preciso mudar e mudar já.

Prensky $(2009,2011)$ retomou essa temática e fez alguns esclarecimentos a respeito desses conceitos devido a algumas críticas que recebeu. Ele se disse surpreso e chocado com a violência das discordâncias sobre o que ele chamou de "metáfora sobre nativos e imigrantes digitais" e que esta não deveria ter sido tratada tão literalmente. Por isso, quase dez anos depois, criou um novo termo: Digital Wisdom - sabedoria digital - um conceito duplo, que se refere tanto à sabedoria resultante do uso da tecnologia digital, quanto ao uso prudente da tecnologia para aprimorar nossas capacidades.

Por causa da tecnologia, os que buscarem sabedoria no futuro se beneficiarão de conceitos anteriores - acesso instantâneo às discussões mundiais em andamento, toda a história registrada, tudo que já foi escrito, enormes bibliotecas de estudos de caso e dados coletados, e experiências simuladas altamente realistas equivalentes a anos ou mesmo séculos de experiência. É importante fazer uso desses recursos e filtrá-los para encontrar o que se precisa (PRENSKY, 2011, p. 18).

Prensky afirma que a tecnologia por si só não substituirá a intuição, o bom julgamento, a solução de problemas, habilidades e uma clara bússola moral. Mas uma pessoa digitalmente sem aprimoramento, por mais sábia que seja, não poderá acessar as ferramentas digitais que estarão disponíveis.

\section{Características da gamificação}

Para isso, é preciso ir fundo nas oportunidades que se apresentam e aproveitar os elementos de gamificação para potencializar o ensino/aprendizagem de línguas. Entre as características mais marcantes da gamificação, segundo Salen e Zimmerman (2004), Kapp (2012), Werbach e Hunter (2012) e Rego (2015), estão:

a) Pensamento de jogo - o modo de pensar e a linguagem se assemelham ao mundo dos jogos. Isso demanda que o educador, o designer de games educativos e o educando possam se encontrar com o uso de estratégias e elementos de gamificação, que promovam engajamento, motivação e mudança de comportamento. Ao professor cabe ficar aberto a 
modos de ensinar mais divertidos e dinâmicos e para isso o pensamento de jogo propicia um repertório bem variado.

b) Superar metas - as metas e os objetivos são parte importante das experiências de aprendizagem. Na gamificação do ensino, assim como nos games, procura-se indicar onde é a "linha de chegada" e, para alcançá-la, é preciso ultrapassar metas e objetivos intermediários. Trata-se de um bom modo de manter o estudante motivado, fazendo-o superar e vencer desafios constantemente. As metas devem ao mesmo tempo ser desafiadoras e alcançáveis. É recomendável não se perder de vista o fim do percurso, indicando como chegar até lá, em mapas que permitam uma visualização que materialize a linha de chegada.

c) Feedback imediato - é um grande aliado na superação de metas. A gamificação fornece feedback o tempo todo e eles servem como sinalizadores para uma mudança de comportamento. Um feedback bem dado (mesmo diante do erro), serve como fator motivacional para mudar hábitos, atitudes, ações e modos de agir. Ele precisa transmitir ao educando (player) a sensação de que ele é importante e faz parte daquele jogo, portanto, deve ser contínuo, coerente, natural, adequado, contextualizado e que traga surpresas e novidades, convidando-o a prosseguir em sua jornada de aprendizagem.

d) Mecânica de jogo - engloba um conjunto de regras sistematizadas, essenciais para um jogo, deixando claro, de maneira intuitiva e leve, como funciona, para onde se vai, onde começa e termina. As regras informam como se joga, a estrutura formal, o suporte e a funcionalidade; podem ser implícitas, fornecidas passo a passo, de acordo com o andamento e, também, instrucionais. Os graus de dificuldade vão aumentando de acordo com a evolução do participante.

e) Níveis de progressão - auxiliam na evolução do jogo/aprendizado, introduzindo informações que promovam o engajamento; fortalecendo e desenvolvendo habilidades que serão necessárias em fases futuras; exigindo mais velocidade; tornando-se mais desafiadores; os níveis devem servir de motivação, portanto, as vitórias nos níveis ("batalhas"), levam aos níveis seguintes em busca da vitória final (ganhando a "guerra"). Apoiam-se em narrativas escalonadas gradativas, que servem para evitar a chatice e o cansaço, combinando elementos muito fáceis ou difíceis.

f) Estética - O design de uma gamificação no ensino deve compreender a preocupação com os detalhes, utilizando bem os recursos, cores, fundos, linguagem, áudios, textos e imagens, adequados à faixa etária a que se destina, similarmente ao que fazem os jogos. Tudo deve contribuir para que o educando se sinta bem ambientado, imerso na experiência do mundo dos games.

g) Aprendizagem colaborativa - A gamificação não pode ficar restrita a um usuário ou educando, não faz sentido ser individualizada, faz-se necessário promover e aproveitar o potencial da aprendizagem colaborativa. É importante incluir elementos que estimulem a construção de um conhecimento coletivo, troca de experiências, crescimento em grupos, desafios engajadores que gerem comprometimento e evite desistências. 
h) Prêmios e recompensas - são utilizados como fatores motivacionais e indicadores de progresso, servem não apenas para serem conquistados e utilizados para adquirir, vantagens, benefícios e direitos, mas também como feedback em relação ao seu próprio desenvolvimento e em comparação com os demais membros do grupo, valorizando sua performance de acordo com seus progressos. Vencer desafios e receber prêmios e recompensas são fatores muito estimulantes.

i) Motivação, competição e cooperação - Caminham melhor quando caminham juntas. Se, em um jogo, o conflito de interesses é inerente à competição, na gamificação deve-se priorizar, sempre que possível, a cooperação na qual trabalhar com os outros se sobressaia em um regime de aprendizagem colaborativa. A competição não deve ser deixada de lado, pois é um grande fator motivacional, mas deve ser estimulada a ser saudável, no intuito de incentivar melhores performances e não somente de impedir que os outros consigam avançar. É bom chegar em primeiro e vencer, mas é recomendado que não se transforme em impedir que os outros também cheguem.

As estratégias de gamificação do ensino de línguas vem crescendo cada vez mais tanto na sala de aula quanto por meio das tecnologias digitais, que facilitam o acesso a educação a distância -, e os dispositivos móveis têm colaborado muito para que isso aconteça. A seguir, é feita uma breve descrição sobre o Duolingo que, além de ser um curso/aplicativo gratuito de ensino de línguas, utiliza algumas dessas características de gamificação e mobilidade.

\section{Descrição do Duolingo 5}

Criado por Luis von Ahn e Severin Hacker, em 2012, o Duolingo é mais comumente conhecido como um curso ou aplicativo para o ensino de línguas a distância (mas poderia também ser considerado, de modo simplificado, como uma plataforma). Acessado por meio da internet, tornou-se popular no mundo inteiro por funcionar em dispositivos móveis (celulares, tablets, iPads, etc.) e também em notebooks e computadores desktops tradicionais.

São oferecidas diversas combinações para a aprendizagem de línguas. E elas ocorrem em pares. Por exemplo, você pode estudar uma segunda língua (L2) a partir de uma primeira língua (L1), já que a metodologia de ensino adotada se baseia na tradução entre a L2 e a L1 ou vice-versa. Em português (brasileiro), até o início da pesquisa em 2016, podia-se aprender alemão, espanhol, francês e inglês. Existiam outras ofertas, mas, caso a escolha recaísse sobre os demais idiomas, por exemplo, chinês, coreano, dinamarquês, esperanto, grego, hindi, holandês, húngaro, indonésio, italiano, japonês, polonês, romeno, russo, sueco, tcheco, turco,

\footnotetext{
${ }^{5}$ As principais características do Duolingo são explicadas ao longo desta seção, mas caso o leitor queira acompanhar de perto o que está sendo dito, é só acessar o site, fazer sua inscrição (cadastro) e começar a aprender. Disponível em https://www.duolingo.com
} 
etc., era preciso optar pela L1 disponível. Aos poucos, as ofertas de idiomas vão sendo ampliadas na L1, de acordo com a demanda dos países.

\section{Análise e considerações sobre o Duolingo}

Esta seção começa com a análise e as considerações sobre o curso-base escolhido para essa pesquisa, de modo a se diagnosticar suas principais características. Não há aqui a intenção de se esgotar o assunto, mas sim ajudar a compreender porque este curso/aplicativo faz tanto sucesso pelo mundo afora e, simultaneamente, investigar aquilo que é, ou deveria ser, seu principal objetivo: o ensino de línguas.

Logo após o cadastramento, que é bem simples - bastando um e-mail válido e uma senha -, percebe-se alguns padrões de interação, com fácil reconhecimento da interface que prima pelo alto grau do que se costuma chamar de affordance ${ }^{6}-$ um traço muito comum aos jogos digitais - e como o Duolingo adota a estratégia de gamificação, esta parece ter sido uma das principais preocupações de seus designers.

Posteriormente às devidas configurações básicas de definição da quantidade de lições que serão feitas por dia - de acordo com a disponibilidade do aprendiz -, podem ser estabelecidos tempos médios (de $5,10,20,30 \ldots$ minutos) nos quais se fará uma ou mais lições. Isso vai nortear o ritmo dos estudos diários. Sendo a participação diária uma das peculiaridades do Duolingo, já que na metodologia adotada, a prática e o reforço são exigidos. A quantidade de lições delimitadas inicialmente pode ser alterada a qualquer momento, para mais ou para menos, a única obrigação é o compromisso diário.

Ao se olhar pela primeira vez a estrutura do Duolingo, nota-se a árvore (mapa) composta de unidades e lições. $O$ estudante consegue ver um começo, meio e fim. Isso acaba por demonstrar que há um planejamento a ser seguido. Sabe-se desde o início aonde se vai chegar (ao final há uma corujinha sobre um pódio). Como chegar até lá? Conforme Salen e Zimmerman (2004), o modo como o curso está estruturado vai conduzir o usuário pelas mãos em segurança, com sua arquitetura gamificada, seu personal trainer, seus gráficos, barras, dados estatísticos e interface didática.

A mecânica de jogo (SALEN e ZIMMERMAN, 2004) adotada pelo Duolingo deixa claro, de modo leve e intuitivo, como funciona, por onde se inicia e para onde se vai. Na primeira tela que aparece ao entrarmos no site/aplicativo, vê-se uma unidade colorida e todas as

\footnotetext{
${ }^{6}$ Affordance é um termo criado por James Jerome Gibson - psicólogo americano, que muito contribuiu no campo da percepção visual - e que pode ser explicado de maneira simplificada como o potencial de um objeto de ser usado como foi projetado para tal. É a qualidade de um objeto que permite a identificação de sua funcionalidade sem a necessidade de explicação prévia, o que ocorre intuitivamente ou baseado em experiências comuns (por exemplo, uma maçaneta, os ícones de um programa de computador, placas indicativas, botões de ligar e desligar etc., que nos remetem ao universo cotidiano, revelando sua função). Quanto maior for a affordance de um objeto, melhor será a identificação de seu uso.
} 
demais em cinza. Só se pode começar por ali, pela colorida, as demais estão bloqueadas. Isso é perceptível visualmente. O curso quer que o estudante inicie sua jornada pela porta de entrada que ele definiu. Depreende-se uma estrutura, a princípio, linear - sem entrar no mérito de sua eficácia pedagógica - e, como primeiro contato, cumpre sua função de introduzir o usuário no universo do curso e apresentar sua metodologia de ensino. A posteriori - quando as unidades já estiverem liberadas, à medida que forem sendo feitas e desbloqueadas -, a estrutura que era linear poderá deixar de ser, cabendo ao aluno definir sua ordem de prática e reforço das lições em um acesso não linear.

A estrutura da árvore, a ordem em que as unidades aparecem (com suas respectivas classes de palavras e assuntos abordados) e o léxico apresentado são praticamente os mesmos nos quatro idiomas que fazem parte deste estudo. A despeito de ter-se utilizado a língua francesa como exemplo, poderia ter sido qualquer outra. A descrição não teria muita variação. Leffa (2016, p. 145) ao abordar os aspectos que chamaram sua atenção no Duolingo destaca "o uso de um mesmo corpus para as diferentes línguas".

Logo no início da primeira lição - ao se ler um enunciado pedindo para selecionar a tradução da expressão "a mulher" -, obtém-se a ajuda da ilustração (facilitadora) na qual aparecem as imagens sociais mais comuns de uma mulher, ${ }^{7}$ de uma criança e de um animal (gato).

É inevitável não associarmos "la femme" (francês); "die Frau" (alemão); "the woman" (inglês); ou "la donna" (italiano) aos vínculos correspondentes consagrados em português, o mesmo acontece com "criança" e "gato", que aparecem ao lado de "mulher" e, posteriormente, na sequência da lição. Além do acompanhamento de um áudio (forma fonológica), no qual se ouve a pronúncia na língua-alvo de acordo com a representação na respectiva convenção escrita. Antes do clique no botão VERIFICAR, pode-se percorrer e ouvir o áudio de todas as opções. O botão VERIFICAR leva o estudante a um feedback imediato, outra característica do ensino gamificado (KAPP, 2012).

Esse início tem um grau de dificuldade bem baixo o que leva o aprendiz a acertar e ganhar confiança e motivação, mexendo com seu lado emocional de maneira positiva. E mesmo que se erre, há um feedback simples explicando que a resposta estava errada e uma nova oportunidade, com uma pergunta semelhante, lhe é dada.

A correção fraterna, por meio de um feedback positivo, é levada a sério pelos criadores do curso. Percebe-se, também, uma preocupação em "ouvir" aquele que faz uso desta plataforma de ensino de línguas. Por isso a renovação é constante, os designers procuram incorporar melhorias ou consertar aspectos que os usuários não gostam. Muitas vezes a partir de sugestões dos próprios estudantes. Porém, essas alterações são feitas somente após testes de checagem, segundo informações do próprio Duolingo. ${ }^{8}$

\footnotetext{
${ }^{7}$ Apesar da importância do tema, optou-se aqui pela não incidência mais profunda sobre questões como: que imagens sociais comuns são essas? Segundo quais critérios? Etc. Isso daria outra dissertação.

${ }^{8}$ Gina Gotthilf, vice-presidente de marketing e crescimento do Duolingo, disse que diariamente, considerando
} 
Um exemplo disso é um atributo muito comum aos games: o sistema de vidas. Estudos anteriores sobre o Duolingo abordaram questões como a "perda de vidas" representadas por corações (LEFFA, ${ }^{9}$ 2014, 2016; PETIT, 2013), mas isso não se aplicava mais no início de 2018. Justamente por estar em constante desenvolvimento e aperfeiçoamento, foi descartado, tornando a estratégia motivacional mais amigável para os que se sentiam desestimulados ou excluídos, diante do esgotamento do número de vidas a que se tinha direito, e a consequente obrigatoriedade de voltar à estaca zero.

Esse tipo de desafio foi substituído por recompensas ou uma correção mais fraterna, do tipo "quase certo", e a posterior oportunidade de mostrar a compreensão - percebida a partir de uma correção amistosa -, em exercícios subsequentes dentro da mesma lição. Diminuindo, consequentemente a sensação de frustração para aqueles que não estão acostumados com o mundo dos games, conforme se pôde perceber por mensagens nos fóruns e conversas para a pré-seleção de participantes dessa pesquisa.

Durante o estudo para esta pesquisa foi possível perceber outros aprimoramentos, ${ }^{10}$ que após as devidas análises, foram melhorados nas novas versões do curso. Ou seja, as correções, aperfeiçoamentos e ajustes estão sempre ocorrendo. Apesar de não ser um ambiente com estrutura aberta, os idealizadores estão atentos às demandas mediante o uso da opção REPORTE UM PROBLEMA, pela qual são informados dos "erros", bugs e incongruências percebidos pelos usuários. Um exemplo de ajuste que pode vir a ocorrer é sobre a perda total dos dias de ofensiva, que foi considerada como desmotivadora pelos usuários. Vale lembrar que o uso de lingotes só garante imunidade de um dia, mas precisa estar ativado na lojinha e não foi considerado suficiente pela maioria dos participantes da pesquisa.

No que se refere aos recursos das tecnologias digitais, gamificação, motivação, usabilidade, affordance, sensação de prazer, premiações e recompensas por comprometimento e dedicação, competitividade, interface amigável e interativa, atualizações, melhorias constantes dos aplicativos dos dispositivos móveis, lojinhas, superpoderes etc. -, o Duolingo cumpre bem o seu papel, mas faz-se necessário aqui abordar também o ensino propriamente dito, sua estrutura, metodologia e estratégias.

\footnotetext{
todas as áreas da empresa, são realizados 20 tipos de testes diferentes com usuários. Cada um dos testes é aplicado para um grupo aleatório de cerca de 20 mil pessoas. A ideia é que toda estratégia seja validada antes de virar uma "mudança". Os testes controlados diminuem as perdas de tempo e dinheiro, pois mais de $50 \%$ deles se mostram ineficazes. Disponível em https:/epocanegocios.globo.com/Empresa/noticia/2017/09/como-oduolingo-inovou-para-chegar-aos-200-milhoes-de-usuarios.html (acessado em 15 de dezembro de 2017).

${ }^{9}$ Tive a oportunidade de conversar com o professor Vilson Leffa, durante a realização do 7ํ Seminário Hipertexto e Tecnologias da Educação (em dezembro de 2017) e ele mesmo compartilhou a sensação de frustração pela perda de vidas, quando de sua pesquisa para escrever um artigo sobre o Duolingo. Ao ser informado sobre a alteração, ficou contente com a mudança de estratégia adotada pelo curso.

10 Premiações por desempenho; novas recompensas; desafios; a inclusão do chamado "quase certo" (tanto na escrita quanto na pronúncia); fim da ideia de traduzir a web; mais exercícios de tradução para a língua-alvo em vez do contrário; novas oportunidades de compreensão dos ensinamentos, em vez da simples repetição do mesmo exercício na mesma ordem etc.
} 
A tradução entre a língua-alvo (a que se quer aprender) e a língua-base (a que se utiliza para aprender) ou vice-versa, bem como a repetição e o reforço para fixação, são as características preponderantes da metodologia utilizada. Para viabilizar a aquisição lexical, inúmeras vezes, criam-se frases descontextualizadas e quase sem sentido, apenas para encaixar o vocabulário que foi aprendido nos blocos de lições que compõem as unidades.

É claro que o fazem de uma maneira pela qual o estudante acaba relevando essas idiossincrasias da metodologia, principalmente por intermédio de compensações de percepções visuais (gráficos, barras de preenchimento de desempenho, feedbacks positivos...) ou de recompensas por acertos. Pouco importando se você traduziu "I'm a woman" ou "Je suis une femme" como "Eu sou uma mulher", mesmo que você não seja. $O$ que importa é que você acertou e continua satisfazendo sua sensação de saber e sendo parabenizado por isso. A estrutura e o formato dos exercícios privilegiam cumprir metas e avançar como em um jogo.

A fragmentação da língua também não pode deixar de ser observada. O Duolingo adota exercícios e atividades que vão quebrando a língua em vários pedaços, mas que atendem às possibilidades de tradução mecânica e simples, factíveis para os aprendizes em estágio inicial, assim como para as máquinas limitadas à alimentação que recebem dos programadores. Afinal, as dificuldades de tradução são inevitáveis com frases mais longas e complexas. Começa-se por palavras (substantivos, adjetivos, pronomes, artigos...) que são seguidas pela introdução de verbos e suas respectivas conjugações (que vão ficando mais trabalhosas ao longo das unidades), e assim vão se formando frases e mais frases. Mas que não passam disso.

Não há diálogos na árvore (mapa), nem sequer pequenos textos de duas ou mais linhas, são sempre frases; no máximo, orações - reiteradamente isoladas, descontextualizadas e sem interação. Não há perguntas ou proposições cujas respostas não possam ser previstas. Elas são o tempo todo limitadas ao que a máquina espera que seja respondido. A falta de interações reais, que poderiam ser sanadas nos fóruns, acaba não acontecendo, pois estas são feitas na língua do aluno e a língua-alvo é tratada apenas como objeto e não como forma de interação, comunicação e prática.

As dificuldades em se trabalhar as outras habilidades, que em geral ficam em segundo plano neste método, foram minimizadas pelos avanços tecnológicos de reconhecimento de voz (placas de som, microfones, fones de ouvido, alto-falantes...) que agora permitem a prática da oralidade e da audição, ainda que somente para os áudios previamente programados.

A retomada de um método de ensino que foi bem-sucedido no passado, mas que já foi superado por outros que o sucederam e se mostraram mais eficazes, chega a ser paradoxal, pois une tecnologias digitais avançadas com uma metodologia que recoloca o aprendiz em uma posição de mero receptor e não como agente produtor e autor de seu próprio discurso. 
Os idealizadores do Duolingo optaram por criar uma estrutura que pudesse ser funcional e viável, tanto do ponto de vista da gamificação quanto do ensino de línguas, além, é claro, de manter baixos os custos operacionais. Conseguiram fazer uso das tecnologias digitais disponíveis com relativo êxito, já que o número de usuários não para de crescer e pela satisfação dos usuários. Sobre a eficácia e qualidade da aprendizagem, vamos responder ao longo deste artigo.

\section{A pesquisa e suas questões norteadoras}

O recorte aqui apresentado é oriundo de uma pesquisa qualitativa para a qual foram selecionados participantes adultos - falantes de língua portuguesa, sem instrução formal da língua-alvo -, que fizeram testes de nivelamento ${ }^{11}$ comparativos (iniciais e finais), ${ }^{12}$ com o propósito de averiguar a aprendizagem de línguas adicionais. O curso-base escolhido para os participantes foi o Duolingo. Também foram agregados outros meios digitais de educação aberta, disponíveis para prática, interação, aperfeiçoamento e desenvolvimento de competência linguística.

\section{Respostas às questões norteadoras da pesquisa}

Questão norteadora 1: É possível aprender uma segunda língua por meio do Duolingo e quanto se aprende?

Os participantes que estudaram Alemão e Francês conseguiram resultados expressivos alcançando o nível $\mathrm{A} 1$ com média de $71 \%$ de aproveitamento, e com crescimentos dos primeiros testes (quando foram considerados $\mathrm{A} 0$ ) para os testes finais (quando atingiram o nível A1) de $91,8 \%$, em média. Vale frisar, ainda, que apesar de ter ficado com $52 \%$ de aproveitamento, o participante de inglês, alcançou um percentual de melhora de 73,3\%, portanto, não pode ser reduzido a "não ter atingido o nível A1". Em contrapartida, apesar de ter alcançado $60 \%$ de aproveitamento, o participante de italiano só teve uma melhora percentual de $9,09 \%$.

O tempo médio de estudo foi de 14 meses. O número de lições feitas (medidas por $\mathrm{XPs}^{13}$ ) também merece ser levado em consideração, pois está diretamente ligado ao

\footnotetext{
11 Um dos critérios para a admissibilidade como participante da pesquisa era se submeter a um teste de nivelamento que obedecesse à classificação do CEFR (Common European Framework of Reference for Languages - Quadro Europeu Comum de Referência para Línguas), que varia de A1 a C2 - sendo A1, Iniciante e C2, Proficiente.

12 Nesta pesquisa foram exigidos desempenhos iguais ou superiores a $60 \%$ de aproveitamento para serem considerados nível A1. Abaixo disso, existem classificações que consideram os percentuais entre 30 e $59,9 \%$ como pré-A1. Aqui, para facilitar, adotamos a nomenclatura A0 para englobar todos que não atingiram $60 \%$.

${ }^{13} \mathrm{XP}$, de eXPerience (pontos por experiência). O nível de desempenho é contado a partir do total de XP
} 
desempenho alcançado. Os que tiveram maiores percentuais de crescimento foram os que completaram a árvore (Alemão: crescimento de 112,5\% e Francês: crescimento de 130\%). Isso dá indícios que demonstram que cursar o Duolingo regularmente leva a resultados de aprendizagem mensuráveis.

Não se pode deixar de fora também o outro participante de Francês que optou por fazer devagar e praticar continuamente as lições para melhorar a fixação. Mesmo tendo feito apenas $28,5 \%$ da árvore, conseguiu um aproveitamento de $76 \%$ no teste de nivelamento final. Significando que fazer com qualidade, mesmo que em menor quantidade, também gerou aprendizagem.

Esses números corroboram a metodologia adotada pelo Duolingo, que enfatiza a prática contínua, repetição e reforço. Mas que tipo de aprendizagem foi essa? O curso-base escolhido opta pelo ensino por meio da tradução de textos entre L2 e L1 e/ou L1 e L2 e ensino gramatical. Segundo os dados apresentados pelos participantes, todos enalteceram o ganho lexical e sintático, mas se queixaram da baixa capacidade comunicativa. Ou seja, apesar da perceptível melhora demonstrada pelos números anteriores, os participantes não se sentiram seguros para se comunicar na língua estudada, o que, segundo a abordagem comunicativa, significa retirar da língua suas principais funções: comunicar, expressar ideias, informar... (LEFFA, 2016).

Mesmo com as características peculiares do Duolingo - que utiliza a L1 para aprender a L2, utiliza frases soltas (muitas delas artificiais), não se aprofunda em textos e diálogos, não valoriza a produção própria, etc. -, o ganho de vocabulário não pode ser desprezado. Houve efetivamente uma aprendizagem lexical e, também, sintática (que permitiu o reconhecimento de gêneros textuais e das estruturas gramaticais das línguas, ainda que parcialmente). Por isso a leitura foi a habilidade mais destacada pelos participantes, pois sua natureza auxilia nas estratégias de compensação, por meio da ativação dos processos de rememoração (revocação), que acabam sendo acionados ao se encontrar palavras que se conhece o significado, utilizadas em contextos que facilitam a compreensão.

Resumindo: No que se refere à primeira questão, a resposta é um "sim com ressalvas", pois os números demonstraram que houve aprendizagem, mas esta foi parcial e com ênfase nos aspectos lexicais e sintáticos, sem avanços significativos quanto à capacidade comunicativa, pelo menos neste curto período de tempo de duração da pesquisa e de acordo com a amostragem deste estudo qualitativo. Devido à escassez de tempo, não foi possível mensurar se a continuidade dos estudos por períodos maiores possibilitaria avançar além do nível A1. Deve-se salientar, também, que apesar de ter havido aprendizagem, esta difere da preconizada por Freire (1996) e com a qual este pesquisador concorda, pois a metodologia

acumulados. Trata-se, portanto, de uma unidade de medida da quantidade de lições diárias completadas pelos aprendizes - a cada lição concluída dentro de uma unidade, o usuário soma um número de XP (normalmente, 10 por lição). As lições podem ser feitas mais de uma vez, e a cada vez que são feitas, isso gera novo acúmulo de XP. Cada estudante pode definir a quantidade mínima de XP que cumprirá por dia, de acordo com seu plano de estudos. Essa quantidade pode ser alterada ao longo do curso, bastando ajustá-la nas configurações do seu perfil. 
adotada não colabora para a produção ou construção própria e nem gera pensamento crítico. Há que se destacar que o Duolingo faz bom uso de tecnologias digitais (principalmente de dispositivos móveis com acesso a internet) e de características de gamificação. Por isso considerou-se outros pontos, também investigados, e que podem contribuir para superar as limitações encontradas. Passemos à segunda questão norteadora.

Questão norteadora 2: Como a gamificação no ensino de línguas é utilizada por esse curso? Neste aspecto, as contribuições foram mais efetivas e várias das características de gamificação acabaram sendo utilizadas de maneira positiva (SALEN e ZIMMERMAN, 2004; KAPP, 2012; REGO, 2015). Os participantes elogiaram o feedback imediato (que gerava motivação, noção de importância, correção positiva); a superação de metas (como fios condutores, que mantinham os aprendizes dispostos a vencer desafios intermediários e que serviam de ponte para a meta final, a obrigatoriedade de cursar o Duolingo diariamente, gerando disciplina e regularidade); a mecânica de jogo e os níveis de progressão (que mostravam as regras levemente, quase de maneira intuitiva, o estilo passo a passo, etapas com dificuldades gradativas, exigências que iam aumentando aos poucos, as vitórias que levavam a novos níveis, desbloqueios de seções); a estética (a boa utilização de cores, gráficos, imagens que auxiliavam na compreensão e resolução das lições); a aprendizagem colaborativa (que se não chegou a ser exercida de maneira contundente, pelo menos foi apresentada e percebida, pois os participantes tinham a quem recorrer nos fóruns e dentro do grupo); os prêmios $e$ recompensas (a conquista de lingotes para comprar benefícios, fazer apostas, os brasões e títulos, a valorização da performance, o prazer de vencer desafios); a motivação, a competição e a cooperação (foi destacada a competição sadia e sua característica intrínseca de fator motivacional, mas em relação à cooperação esta se manifestou por meio dos fóruns com a mesma limitação percebida na aprendizagem colaborativa).

Quanto ao pensamento de jogo (WERBACH; HUNTER, 2012; PRENSKY, 2001) percebeuse que faltou um maior entrosamento entre os criadores do curso e os educadores envolvidos com o ensino/aprendizagem de línguas, visto que em termos de características de gamificação os elogios foram enormes, mas quanto à metodologia adotada, esta ficou em segundo plano, não conseguindo atingir adequadamente alguns aspectos do ensino/aprendizagem de línguas como, por exemplo, a melhoria da competência comunicativa. Leffa (2014) considera o Duolingo bem planejado quanto à "jogabilidade", mas insuficiente quanto ao conceito de língua, por esta não ser tratada como um instrumento de comunicação.

Ao longo da coleta/geração de dados do Grupo A, os participantes destacaram a estrutura com início, meio e fim da árvore do Duolingo; saber aonde se vai chegar; a regularidade; cumprimento de metas diárias; facilidade de entendimento da mecânica do curso; a competitividade entre os membros do grupo; o modo como as lições foram estruturadas; a apresentação, imagens, gráficos...; os aspectos motivacionais; o feedback imediato; as recompensas; os lingotes; o fato de se estudar sem perceber; a disponibilidade de uso em várias plataformas; enfim, quase tudo que foi abordado nos parágrafos anteriores 
e que foi apontado pelos estudiosos do assunto como algumas das principais características da gamificação.

Questão norteadora 3: Como as tecnologias digitais contribuíram para isso? A contribuição das tecnologias digitais foi marcante tanto para fazer o curso-base (foram utilizados computadores [desktop], notebooks, tablets e celulares) quanto para utilizar outros recursos adicionais, principalmente em dispositivos móveis, que foram elogiados por todos os participantes, tendo em vista que facilitaram o acesso à educação online. E essa mobilidade, conjugada com o acesso a internet, ampliou as oportunidades, na medida em que possibilitou o estudo, a prática e o aperfeiçoamento dos participantes do Grupo A. Além disso, foi possível interagir com outros membros do grupo, mesmo estando em pontos distintos (SANTOS, 2010).

Porém, a educação online não pode ser avaliada simplesmente pelos equipamentos ou ambientes de aprendizagem, é preciso aferir as ações dos sujeitos que nela agem. Ainda que as interfaces possibilitem e/ou ampliem as oportunidades, é fundamental o uso que delas se faz, no que se refere especialmente à interatividade e à comunicação.

\section{Considerações finais}

A ampliação do acesso às tecnologias digitais não garante por si só os resultados. Ao longo da pesquisa, percebeu-se que ainda não existe uma pedagogia específica consagrada ou que sirva de modelo a ser seguido, justamente pelo fato de a educação online aberta ocupar um espaço recém-descoberto - por isso ainda são aplicadas, no novo ambiente de ensino, práticas que obtiveram sucesso, mas que são pertencentes a outras épocas e meios. São pedagogias em construção, que vão emergindo em meio às novas descobertas, adaptadas às condições tecnológicas e recursos disponíveis em um mundo globalizado e com realidades bem distintas.

As tecnologias digitais - em especial as de acesso à internet - facilitam a vida de quem quer obter novos conhecimentos (no contexto dessa pesquisa os que se referem à aprendizagem de segunda língua). No Brasil, por exemplo, o uso do telefone celular se consolidou como o principal meio para acessar a internet, conforme a Pesquisa Nacional por Amostra de Domicílios (Pnad) 2015, divulgada em 2016 pelo Instituto Brasileiro de Geografia e Estatística (IBGE). ${ }^{14}$ Muitos que não têm um computador, conseguem acessar a web por meio desse dispositivo, que evoluiu muito e - para algumas finalidades - se equipara às capacidades de processamento e de recursos dos microcomputadores.

\footnotetext{
${ }^{14}$ Disponível em: https://biblioteca.ibge.gov.br/visualizacao/livros/liv98887.pdf. (Acessado em 22/12/2016.)
} 
Diante desse quadro, são vários os estudos que buscam identificar e aprimorar novas pedagogias, mais bem adequadas a essa realidade digital, e uma das que obtiveram relativo sucesso nesses novos tempos, foi a gamificação do ensino (uma prática existente há milhares de anos, mas que ganhou uma nova roupagem com as atuais tecnologias digitais). É preciso que utilizemos de modo mais eficaz as características dos jogos digitais no ensino.

Características dos jogos - como motivação, engajamento, feedback imediato, desafios, comprometimento, trabalho em equipe, recompensas pelo trabalho árduo... - vêm sendo utilizadas com frequência nesse início de século XXI, em vários âmbitos, inclusive na educação, por se adequar ao tipo de pensamento das novas gerações que já nascem em um mundo cada vez mais digital, conectado, multimídia, hipertextual. Não se pode esquecer, é claro, da aprendizagem colaborativa, que foi potencializada pelas tecnologias digitais e oportunidades de socialização no ciberespaço (SANTOS, 2010).

Tem-se a falsa impressão de que é possível interagir e dialogar com máquinas. Mas esse é um grande engano, pois a interação, para ser de verdade, pressupõe a existência de um interlocutor real e não de uma máquina desenvolvida para responder segundo sua programação. Ainda que tenha sido abastecida por uma quantidade enorme de opções, ela é limitada. Em última instância, as máquinas só são capazes de fazer aquilo para o que foram programadas, ainda que a inteligência artificial venha se desenvolvendo muito nas últimas décadas. Sabedores disso, podemos ao menos entender as limitações do curso Duolingo e de tantos outros que existem na internet.

As TICS deveriam ser vistas como meios pelos quais pode-se exercer o ensino/aprendizagem. Elas são apenas instrumentos e continua cabendo aos educadores decidir como bem utilizá-las. Para isso, contudo, é necessário que haja um diálogo franco e aberto entre os que sabem como criar e desenvolver material adequado para as TICs e os que possuem a competência sobre o conhecimento, mas ainda estão engatinhando na produção destinada a esse universo digital tecnológico (PRENSKY, 2001; SANCHO, 2010).

O ensino/aprendizagem, a contextualização, a coerência, o pensamento crítico, as funções da língua, a aprendizagem colaborativa, a autonomia, a autoria, as interações de comunicações autênticas, etc. acabam ficando em segundo plano. E isso pode ser atribuído por esta falta de diálogo entre "os que dominam as técnicas de fazer materiais que atendam às demandas dos sujeitos que utilizam as tecnologias digitais" e os que "dominam esse tipo de conhecimento destacado nas primeiras linhas deste parágrafo".

A tradução atua como facilitadora da falta de tempo e espaço na sala de aula (com dezenas de alunos, nas escolas públicas principalmente) assim como no curso ora estudado. Contudo, é preciso que o educando aprenda a língua de modo que ele deixe de ser apenas um receptor, que passe a interagir, enfim, se comunicar, provocando um movimento inverso de fazer a periferia chegar ao centro, de transformar objetos em sujeitos. Concordando com a opinião de Leffa (2016), não dá mais para continuar tratando o ensino de língua destituindoa de suas funções essenciais que são comunicar, falar de nós, falar do mundo, agir sobre si e 
sobre o outro, expressar nossas ideias e pensamentos, informar, mostrar nossa perspectiva, ou seja, dar vazão à nossa voz.

O curso-base adotado foi considerado insuficiente quanto à competência comunicativa. Contudo, fazer o curso - associado a outras estratégias de aprendizagem regulares e conscientes - pode levar os participantes a agilizar a conquista e o desempenho dessa e de outras competências, desde que aliado a outros recursos e estratégias.

A pesquisa mensurou, conforme Demo (2009a) e Kenski (2013), que as competências podem ser aperfeiçoadas se acompanhadas de estratégias de aprendizagem combinadas e adequadas ao educando, além de organização, disciplina, iniciativa, autoquestionamento, aprendizagem colaborativa, pensamento autocrítico, enfim, escolhas qualitativas que acontecem quando há liberdade para exercitar os processos de autonomia.

A gamificação adotada pelo curso teve o mérito de manter os estudantes comprometidos e engajados em boa parte do tempo. E estudar é o melhor caminho para aprender. Apesar de todas as questões aqui discutidas, o Duolingo apresenta-se como uma boa chance para os que, em geral, não têm oportunidade alguma. O curso consegue manter as pessoas estudando (de maneira divertida) e isso, por si só, já é um fato relevante.

Construir uma escola que motive, que proporcione aprendizagem e que eduque para a construção de um saber colaborativo e crítico é a meta. E a educação online aberta, associada às tecnologias digitais, é uma grande parceira nesse sentido de dar oportunidade, não uma qualquer (por isso essa pesquisa foi feita), mas uma oportunidade que leve educandos e educadores a se tornarem sujeitos e não apenas objetos. É preciso deixar de lado a postura de apenas receber. Deve-se exercer o direito de construir os processos de ensino/aprendizagem.

Há um grande potencial ainda inexplorado. As tecnologias digitais estão se encarregando de gerar novas oportunidades para educadores e educandos, principalmente, os preocupados com a construção de conhecimentos críticos e autorais. Basta que consigamos ultrapassar os medos e vícios limitantes de pensamentos presos no tempo e/ou no espaço. Não adianta termos suportes e não termos conteúdos, pedagogias e metodologias adequadas; precisamos aprender a dar prosseguimento ao que se aprende; precisamos, sobretudo, avançar no modo como se usa o progresso tecnológico para a aprendizagem coletiva e colaborativa e isso só vai ser possível pela mudança do status quo, adotando-se um padrão de que possibilite processos efetivamente educativos plurais.

A efemeridade do saber não permite acomodações, é necessário que educadores e educandos aprendam a pensar criticamente, que saibam utilizar as línguas, seja L1 ou L2, para respeitar aquilo que Freire (1996) já dizia no milênio passado - é essencial criar e dar condições para fazer brotar e crescer uma vontade de saber que levará o sujeito aonde ele desejar. 


\section{Referências}

ARAÚJO, J.; LEFFA, V. (Org.). Redes sociais e ensino de línguas: o que temos de aprender. 1. ed. São Paulo: Parábola Editorial, 2016.

CARDOSO, J. S. Online games: homework can be fun. Mindbite. Aplierj Newsletter, dec. 2014 / feb. 2015. ISSN 1678-6149. Rio de Janeiro, 2014.

DEMO, P. Educação hoje. São Paulo: Atlas, 2009a.

DEMO, P. Revista Brasileira de Docência, Ensino e Pesquisa em Educação Física, v. 1, n. 1, p. 53-75, ago. 2009b.

DUOLINGO (site). Disponível em <https://www.duolingo.com>. Todas as telas foram capturadas ao longo de 2017, de acordo com o andamento das atividades desenvolvidas pelos participantes da pesquisa.

FREIRE, P. Pedagogia da autonomia: saberes necessários à prática educativa. São Paulo: Paz e Terra, 1996.

KAPP, K., M. The Gamification of Learning and Instruction: game-based methods and strategies for training and education. São Francisco: Pfeiffer, 2012. https://doi.org/10.1145/2207270.2211316

KENSKI, V. M. Tecnologias e tempo docente. Campinas: Papirus, 2013.

LEFFA, V. J. Gamificação adaptativa para o ensino de línguas. In: Congresso Ibero-Americano de Ciência, Tecnologia, Inovação e Educação. Buenos Aires. Anais, 2014, p. 1-12.

LEFFA, V. J. Redes sociais: ensinando línguas como antigamente. In: ARAÚJO, Júlio; LEFFA, Vilson (Org.). Redes sociais e ensino de línguas: o que temos de aprender. 1. ed. São Paulo: Parábola Editorial, 2016. p. 137-153.

McGONIGAL, J. A realidade em jogo. Rio de Janeiro: BestSeller, 2012.

OLIVEIRA, L. A. Métodos de ensino de inglês: teorias, práticas, ideologias. São Paulo: Parábola, 2014.

PETIT, T.; SANTOS, G. L. A aprendizagem não formal da língua estrangeira usando o smartphone: por quê voltamos a metodologias do século XIX?. Anais eletrônicos do 5은 Simpósio Hipertexto e Tecnologias da Informação - Aprendizagem móvel dentro e fora da escola. UFPE, 2013. p. 1-21. ISSN 1984-1175.

PNAD. Pesquisa nacional por amostra de domicílios: síntese de indicadores 2015 / IBGE, Coordenação de Trabalho e Rendimento. Rio de Janeiro: IBGE, 2016. 108p.

PRENSKY, M. Digital Natives, Digital Immigrants. In: On the Horizon. MCB University Press, v. 9, n. 5, p. 1-6, out. 2001.

PRENSKY, M. H. Sapiens Digital: From Digital Immigrants and Digital Natives to Digital Wisdom, Innovate, v. 5, 3, 2009.

PRENSKY, M. Digital Wisdom and Homo Sapiens Digital. In: THOMAS, Michael (Ed.) Deconstructing digital natives: young people, technology, and the new literacies. Oxon - UK: Routledge (Taylor \& Francis Group), 2011. p. 15-29 
REGO, I. de M. S. Mobile Language Learning: How Gamification Improves the Experience. Campinas, SP: Unicamp, 2015.

SALEN, K.; ZIMMERMAN, E. Rules of play: games design fundamentals. Cambridge: MIT Press, 2004.

SANCHO, J. M. Para promover o debate sobre os ambientes virtuais de ensino e aprendizagem. In: SILVA, Marco; PESCE, Lucila; ZUIN, Antonio (Org.). Educação online: cenário, formação e questões didático-metodológicas. Rio de Janeiro: Wak Ed., 2010. p. 95-106.

SANTOS, E. Educação online para além da EAD: um fenômeno da cibercultura. In: SILVA, Marco; PESCE, Lucila; ZUIN, Antonio (Org.). Educação online: cenário, formação e questões didático-metodológicas. Rio de Janeiro: Wak Ed., 2010. p. 29-48.

SILVA, M. Cibercultura e educação: a comunicação na sala de aula presencial e online. Revista FAMECOS. Porto Alegre, n. 37, p. 69-74, dez. 2008.

WERBACH, K.; HUNTER, D. For the win: how game thinking can revolutionize your business. Philadelphia: Wharton Digital Press, 2012.

Recebido em: 09/06/2019

Aceito em: 31/10/2019 